\title{
기후변화와 빈곤, 그 위기와 대책
}

오기출(푸른아시아 사무총장)

목 차

I. 시작하며: 빈곤 중심의 새천년개발목표(MDGs)에서 지속가능발전목표(SDGs)로 전환

II. 세계은행의 고민

III. 환경과 빈곤문제 해결의 저해요소

1. 해외식량투자의 딜레마

2. 기후변화로 증가하는 환경난민

IV. 환경과 빈곤문제 대책을 찾아서

1. 국제적 가이드라인의 적용

2. 사례: 지속가능한 토지경영(Sustainable Land Management, SLM) 모델

3. 정보와 아이디어, 지식공유 플랫폼 제안: 테라시아(TerrAsia)를 만들어야

I. 시작하며: 빈곤 중심의 새천년개발목표(MDGs)에서 지속가능발전목표(SDGs)로 전환

유엔이 2000년부터 2015년을 목표로 추진해 온 새천년개발목표는 이제 지속가능 한 발전목표로 전환되고 있다. 2012년부터 본격화된 지속가능발전목표 협상은 이제 막바지 단계에 이르고 있다. 유엔은 지난 2014년 9월 사무총장의 종합보고서 (Synthesis Report)를 발간했고, 2015년 1월부터 정부 간 협상을 시작으로 올해 9월 유엔 총회 특별정상회의에서 지속가능발전목표를 채택할 예정이다.1)

1) 유엔 총회 산하 지속가능발전목표(SDGs) 공개 작업반(OWG)은 2013년 3월부터 2014 년 7 월까지 약 13 회의 회의를 토대로 17 개의 목표와 169 개의 세부목표를 제시하였다. 공개 작업반의 17 개 목표는 일반적인 목표로 빈곤종식(1번)과 불평등(10번), 영역별로 
그 전환의 핵심은 빈곤 중심의 새천년개발목표를 확대하여 환경과 빈곤(경제), 사 회 의제를 통합적으로 적용하여 지구촌에 닥친 위기를 극복하자는 것이다. 환경과 빈곤문제 현안은 이제 한국을 포함한 국제사회가 지속가능한 목표를 위해 중점적으 로 해결해야할 과제로 부각되고 있다. 그래서 지속가능발전목표(SDGs)이다.

이러한 상황을 반영해서 2014년 9월 23일 뉴욕에서 열린 유엔기후정상회의에서 유엔 반기문 사무총장은 이렇게 말했다.

“우리는 자연과 협상할 수 없다, 자연은 우리는 기다려 주지 않는다.” ${ }^{2)}$ (We can not negotiate with mother nature. Mother nature does not wait.)

바야흐로 이제는 환경문제 해결 없이 인류가 생존할 수도 없고, 더욱이 빈곤 문제 도 해결되지 않는 시대에 놓여 있다. 반기문 총장은 이어서 이렇게 정리한다.

"우리는 또 하나의 지구(Planet B)를 갖고 있지 않기 때문에 다른 대안(Plan B)도 없다. 결국 변화하는 상황에 적응해야 하는 존재는 우리 인간 자체이다.” ${ }^{3)}$

\section{II. 세계은행의 고민}

누구나 이런 의문을 가질 수 있다. 지구 환경의 위기와 빈곤문제가 무슨 관계가 있을까? 한국처럼 70년대, 80년대에 환경을 희생하면서 고도성장과 산업화의 경험을 했다면 충분히 가질 수 있는 의문이다. 중국도 환경을 희생시켜 고도성장의 길을 가 고 있지 않는가? 그런 점에서 환경은 경제성장과 빈곤문제를 해결하기 위한 희생의 재물 정도로 생각할 수 있다.

는 지속가능발전의 3 개축인 환경, 사회, 경제발전 분야에서 각각 4 5개의 목표를 설 정하고 마지막으로 책무성과 거버넌스(16번)와 이행수단 및 글로벌 파트너십(17번)을 제시하였다(이성훈, 2014년, 49쪽, 52쪽).

2) 2013년 12월 10일 바르샤바에서 개최한 유엔기후변화협약(UNFCCC) 당사국 총회에서 도 유엔 반기문 사무총장은 “우리는 자연과 협상할 수 없다.”는 말을 했다.

3) 이 유엔기후정상회의에서 반기문 사무총장은 탄소에 가격을 매겨야한다는 것을 강조한 다. 녹색경제를 위해 더 많은 자원을 투자해야한다는 연설문을 통해 기후변화 해결이 유엔의 가장 중요한 목표임을 밝힌다(United Nations, 2014년, www.un.org/en/2014 sgsm16186.doc.htm). 
그런데 지금 환경을 번영의 재물 정도로 생각해온 정책들이 폐기되어야할 시대가 시작되었다. 왜 그럴까? 먼저 다음과 같은 질문을 던져보자.

최빈국들과 개발도상국이 번영을 이루기 위해 환경을 희생시키는 것이 당연할까? 5년 전이라면 지구촌 번영과 빈곤퇴치를 주도해온 세계은행(World Bank Group)도 이러한 질문에 대해 당연하다고 대답했을 것이다.

그러나 2012년 이후 세계은행은 지구촌의 대표적인 환경문제인 '기후변화의 역습' 을 가장 무서운 전염병인 에볼라(Ebola)와 동일한 문제로 다루기 시작했다. 2014년 10 월 10 일 미국 워싱턴에서 개최한 '세계은행 연차총회'에서 김용 세계은행 총재는 다음과 같은 연설을 한다.

"에볼라와 기후변화는 공통점을 갖고 있다. 무엇보다도 중요한 것은 이 두 가지 문 제를 해결할 해법을 찾아야 한다는 것이다. 최근까지도 기후변화와 에볼라를 해결하 기 위한 계획은 존재하지 않았고, 있다고 해도 적절하지 않았다. 우리의 무관심이 우 리 인류를 죽일 것이다. 한편으로 죽음의 바이러스가 빠르게 퍼지기 때문이고 다른 한편으로 대기와 바다에 쌓이는 오염 때문이다.”")

지구촌의 개발과 번영을 이끌어 온 대표적인 국제기관인 세계은행이 지구촌의 환 경문제와 빈곤 문제가 매우 밀접하게 연관되어 있음을 명백하게 드러내고 있다. 70 년대, 80 년대 한국의 경제성장에 돈을 댄 세계은행이 지금 기후변화를 해결하지 않 고는 지구촌의 빈곤문제 해결은 불가능하다고 밝히고 있다. 빈곤으로부터 탈출하고 번영을 이루기 위해 환경을 희생시킬 수 있다는 의견은 지금 세계은행의 정책 중 어 디에서도 찾아볼 수 없다. 세계은행이 지난 2014년 11월에 발표한 '지구촌 온도를 낮 추어야한다' 보고서(The Turn Down the Heat report)에서 '빈곤의 종말은 기후변화 로 인해 불가능하게 될 것이다'고 선언했다. ${ }^{5)}$

4) 이 연설에서 김용 세계은행 총재는 빈곤의 원인을 기후변화, 에볼라에 한정하지 않고 저개발국가의 사회기반시설의 낙후성을 함께 지적한다. 그래서 세계은행이 위의 3 가지 목표를 달성해야 환경과 빈곤문제에 접근 가능하다는 점을 지적한다(World Bank Group president Jim Yong Kim, 2014년).

5) 동 보고서는 중동과 북아프리카, 라틴아메리카와 카리비안, 동유럽과 중앙아시아 등 
이 세계은행 보고서는 현재 인류가 지구온난화를 해결하는 노력을 하지 않으면 21 세기 말에 지구 기온이 $4^{\circ} \mathrm{C}$ 오르게 될 것이고, $20 \sim 30$ 년 안에 $2^{\circ} \mathrm{C}$ 가 오르게 될 것임 을 밝히고 있다.

동 보고서는 지구기온이 $4^{\circ} \mathrm{C}$ 가 오르게 되면 인류가 한 번도 경험하지 않은 열파 (heatwaves)가 지구 전체에 영향을 미쳐, 식량 생산의 $70 \%$ 가 감소해서 인류는 굶어 죽는다고 예고하고 있다. 김용 세계은행 총재는 이 보고서의 서문에 조만간 닥칠 $2^{\circ} \mathrm{C}$ 상승으로 인해서 지구촌의 번영과 빈곤문제 해결은 커다란 난관에 부딪칠 것이 라고 경고했다. $2^{\circ} \mathrm{C}$ 가 오르면 지구촌의 농업은 $30 \%$ 가 줄어들게 되고, 안데스 산맥의 빙하는 $90 \%$ 가 사라지게 된다는 것이다. 이 시나리오에 따르면, 지구 전체가 지금부 터 온실가스를 전혀 생산하지 않는다고 해도 $1.5^{\circ} \mathrm{C}$ 가 오르게 된다고 한다. 그러면 지 구촌에 사는 70 억 명 인구 중 12 억 명이 극단적인 빈곤의 덫에 갇히게 되고, 이들의 삶은 개선되지 않을 것임을 예고하고 있다.

세계는 현재 기후변화와 전쟁 중이다. 세계은행의 이런 고뇌는 지난 2014년 9월 '유엔기후정상회의(UN Climate Summit)'에서도 드러났다. 기후변화를 유발하는 탄 소에 가격을 매긴다는 결정이다. 그 동안 이산화탄소는 경제성장을 위해 불가피한 것이라고 생각했다. 이를 발생시키는 것은 공짜였다. 그러나 2014년 세계은행이 제 안을 하면서 유엔기후정상회의에 참여한 73 개의 나라들과 1,000 개의 대규모 기업들 이 탄소에 가격을 매겨 기후변화 저감을 한다는 협약에 사인을 했다. ${ }^{6)}$ 온실가스를 저감하는 청정 경제를 만들어가는 데 투자를 하고 여러 가지 기후행동들을 만들어가 는 기반에 투자를 하기 위해서다. 기후변화 저감을 위해 필요한 조치로 탄소에 가격 을 매기는 것에 정부 수반들과 기업들이 기꺼이 동의한 것이다. 이 날 매우 중요한 한 줄의 선언문이 만들어 졌다. "부국이든 빈국이든 기후변화 재앙으로부터 면역력을 갖고 있는 나라는 하나도 없다.”7)

전 세계의 기후변화 결과를 종합적으로 정리를 했는데 기후변화의 결과 지구상의 모든 지역이 예외 없이 심각한 영향을 받는다는 경고를 하고 있다(World Bank, 2014년).

6) 2013년 이후 세계은행은 탄소에 가격을 매기는 정책을 전술적으로 접근하는 것이 아 니라 전략적으로 접근한다는 것을 분명하게 하고, 각 국가의 정상들과 기업들에 제안 을 하고 있다(World Bank Group president Jim Yong Kim, 2014년).

7) www.worldbank.org/en/topic/climatechange/overview. 
세계은행의 고민은 현재 유엔과 73 개 국가와 1,000 개의 기업으로 확산되고 2015 년에는 더욱 강력한 공감대를 만들어 갈 것이다. 다음과 같이 말이다.

“환경과 기후변화를 고려하지 않은 경제발전은 앞으로 많은 난관에 부딪힐 게 뻔 하다. 그리고 기후변화로 인한 식량 위기, 물 위기, 가뭄과 홍수의 재앙을 해결하지 않는 한 빈곤문제는 더욱 악화될 것이다.”

\section{III. 환경과 빈곤문제 해결의 저해요소}

\section{1. 해외식량투자의 딜레마}

기후변화에 의한 이상기후는 지구촌의 식량 위기로 연결된다. 한국 농촌경제연구 소 한석호 부연구위원에 따르면, 과거에는 7 8년 또는 10년 주기로 국제 식량가격 등락이 있었지만 2008년 이후에는 그 흐름이 3.2년, 1년으로 점점 짧아지고 있다.8) 그 원인 중 가장 심각한 것은 기후변화다. 이러한 상황은 저개발국의 토지 임차 문 제, 이른바 대자본들이 주도하는 해외 식량기지 확보를 촉발시켰고, 이로 인해 저개 발국의 주민들에 대한 토지 수탈문제가 제기되기 시작했다.

2008년 11월 21일자 로이터통신과 11월 23일자 타임지9)를 비롯해 영향력이 있는 국제 언론은 특정 대자본이 최빈국에서 토지수탈을 하고 있다는 비난 기사를 내보냈 다. 언론들은 한국 기업인 대우 로지스틱스(Daewoo Logistics)가 아프리카 동남부에 있는 마다가스카르 공화국 1 만 3 천 $\mathrm{km}^{2}$ 의 땅을 경작지로 99 년 장기 임대하는 것을 협상 중임을 발표했다. 그 규모는 경상남도의 1.2 배이고 벨기에 전체 국토의 절반에 해당한다. 대단히 큰 땅을 한국의 기업이 $2 / 3$ 는 옥수수 생산을 위해, $1 / 3$ 은 바이오 연료를 얻기 위한 해외 경작지로 임대하려고 했다. 당시 대우 로지스틱스는 한국의 식량안보(Food Security)를 위해 미개간지를 사용하려고 한다고 했지만 국제사회의 반응은 냉담했다. 유엔식량농업기구(FAO)에 따르면 이 규모의 땅은 마다가스카르 경

8) 특히 2008년 이후 그 변동성이 더욱 심화되고 있다. 국제곡물시장은 '엷은 시장(thin Market)'으로 교역량은 생산량의 $10 \%$ 내외이며, 수요에 대해 가격 반응이 비탄력적이 어서 생산량이 조금만 바뀌어도 가격이 크게 변동하게 된다(한석호, 2012년).

9) The Breadbasket of South Korea: Madagascar(Time Vivienne Walt, 2008년). 
작지의 절반에 해당된다고 한다. 세계 3 대 옥수수 수입국이면서 경작지가 부족한 한 국이 찢어지게 가난한 열대 섬나라인 마다가스카르에서 식량을 생산하여 한국으로 가져가기 위한 조치라고 했다. 아울러 그 당시는 기후변화와 건조화, 사막화의 확장 으로 십 수개의 가난한 나라들의 주민들이 치솟는 식량가격을 지불하지 못해 곤경에 처한 상황이었다. 그래서 마다가스카르도 인구 2 천만 명 중 $70 \%$ 가 빈곤선 이하의 수 입으로 고통 받고 있었는데, 마침 세계식량계획(WFP)이 마다가스카르에서 어린이들 을 위한 학교급식계획을 실행하고 있었다. 대우 로지스틱스의 행동은 언론들에 의해 마다가스카르의 주민들에게도 부족한 식량을 한국으로 가져가는 식량수탈행위로 지 목되었다. 이를 계기로 아프리카에서 식량과 바이오 연료를 생산해온 영국의 기업인 선-바이오 연료(Sun Biofuels), 스위스의 네슬레 등 유럽 농업기업, 중동과 중국의 기업들이 아프리카 토지와 주민의 식량을 수탈하는 대표적인 기업들로 비난을 받았 다. ${ }^{10)}$

여기에 대해 아프리카 진출 기업들은 아프리카의 개발기회(development opportunity) 임을 항변한다. 예컨대 수백만 명의 아프리카 농부들은 비료와 기본 농기구, 연료와 운송 장비를 구입할 돈이 부족하기에 효과적으로 농사를 지을 수 없고, 농산물을 시 장에 내놓지 못하고 있다. 그래서 저개발국의 정부가 현명하게 교섭을 한다면 해외 기업들이 아프리카를 개발해서 농민들에게 이익을 줄 수 있음을 호소했다. ${ }^{11)}$

결국 대우 로지스틱스의 경우 이듬해인 2009년 마다가스카르 대통령이 바뀌면서 계약이 좌절된다. 이는 새로운 논쟁을 불러 일으켰다. ${ }^{12)}$

10) 2009년 $F A O$ 의 조사에 의하면 가나, 에티오피아, 마다가스카르, 수단 등지에서 지난 5년간 해외 국가와 체결한 농지투자계약은 영국 전체 경작지 규모와 맞먹는 250만ha 에 달한다. 사우디아라비아 기업 하드코는 당시 수단에서 밀 6만 톤을 생산, 조인트 벤처 자나트는 아프리카에 4,000만 달러를 투자했다. 중국도 아프리카에 2,000개 기 업을 진출시켰다. 중국의 경우 아프리카 투자가 독재정권의 금고만 채워주고 있고, 일자리의 경우 중국인의 채용을 우선시하고 아프리카 국가의 실업난 해소에 도움이 되지 못하고 있다는 불만이 터져 나오는 실정이다(FAO, 2009년).

11) The Breadbasket of South Korea: Madagascar(Time Vivienne Walt, 2008년).

12) 한국 정부와 지자체들은 2008년 곡물 파동이후 식량 안보에 대한 위기를 느끼고 해외 농업 개발에 나섰지만 준비부족으로 이렇다 할 실적을 올리지 못했으며 2009년부터 2013년 해외 농업 개발 추진비로 1,000억 원 이상을 썼다고 한다(김민주, 2014년). 
토지수탈(Land Grab)인가? 개발기회(Development Opportunity)인가?13)

정치적으로 윤리적인 논쟁으로까지 비화된 이 문제의 배경을 살펴보면 이렇다.

유엔사막화방지협약(UNCCD)의 보고에 의하면 기후변화로 인해 지구촌에서 매년 대한민국의 1.2 배 면적에 해당하는 12 만 $\mathrm{km}^{2}$ 의 경작지와 방목지가 사막화되어 사용할 수 없게 된다. 아울러 사막화로 인한 농업과 유목 생산량 손실은 매년 420억 달러 (42조 원)를 넘고, 110 개 나라 21억 명이 직접적으로 피해를 입고 있다고 한다. 유엔 의 통계에 따르면 2050년대가 되면 지구촌의 인구는 90 억 명이 되는데, 현재의 경작 지와 방목지보다 $100 \%$ 이상이 늘어나야 인류가 생존할 수 있다고 보고한 바 있다. ${ }^{14}$ )

문제는 이런 기후변화와 사막화의 심각성이 미래의 문제가 아니라 현재 진행되고 있다는 사실이다. 그 결과 대우 로지스틱스가 마다가스카르에 농업투자를 한 2008년 에 옥수수, 밀, 콩의 국제가격이 짧은 기간 동안 거의 $100 \%$ 이상 상승하기도 했다. 한국농촌경제연구원 자료에 따르면 2006년 6월부터 2008년 4월까지 밀·옥수수·콩의 가격은 각각 $86 \%, 125 \%, 123 \%$ 상승했고 쌀은 무려 $232 \%$ 나 급등했다. ${ }^{15)}$

13) $\mathrm{FAO}$ 를 중심으로 2009년 5월 25일 “Land Grab or development opportunity?" 보고 서가 나오면서 이 문제는 국제사회에 공식적으로 문제제기 된다.

14) 유엔사막화방지협약은 2014년 6월 17일 세계사막화방지의 날을 기념해서 2014년 사 막화로 인한 피해 현황을 정리한다(Louse Baker, 2014년).

15) 2008년 곡물 파동으로 가격이 폭등하자 인도네시아, 아이티, 모잠비크 등 30 여 개국 에서 시위와 폭동이 끊이지 않았다. 2008년 식량가격의 상승은 공급이 수요를 따라 가지 못해 벌어졌다(김민주, 2014년). 
<표 1> 주요 곡물 국제 선물가격 추이

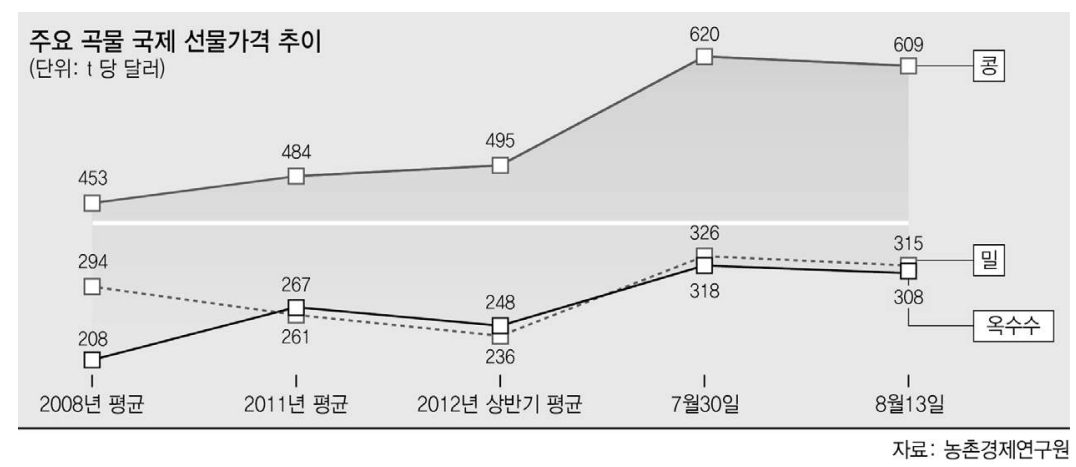

<표 2〉 The Economist online, 국제 곡물가격 추이 2012년 5월 1일

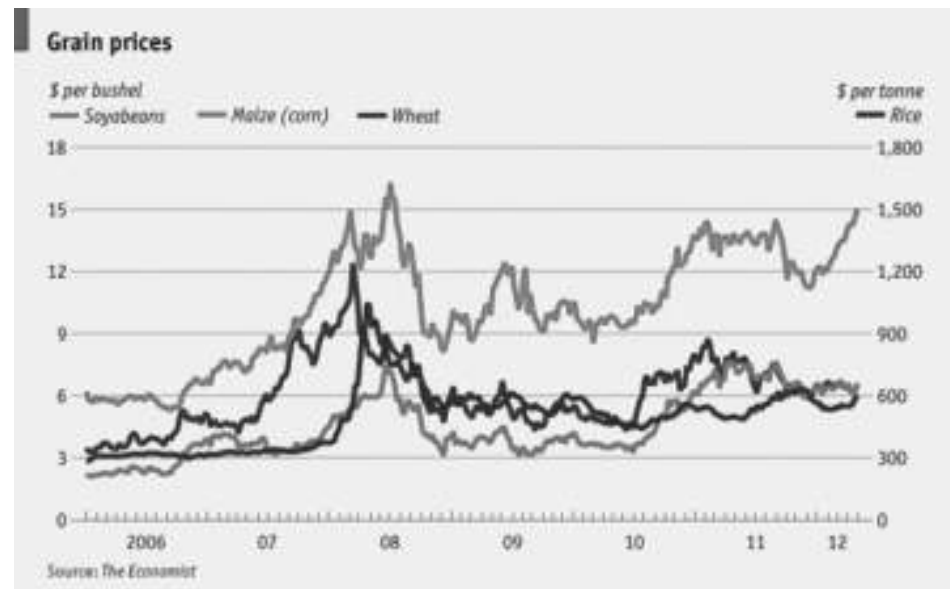

이미 예견되는 식량위기에 대해 대규모 기업들이 반응을 보이는 것은 다음과 같은 이유로 분석된다. 농업 분야의 이익이 급속한 식량가격 상승으로 예상된다는 점과 화석연료를 대체하는 바이오연료의 수요가 급증된다는 점들이 그것이다.

최근처럼 저유가 상황이 온다고 해도 세계은행이 화석연료 개발에 지원하지 않고 청정에너지 개발에 투자를 집중하는 등 기후변화에 대한 국제사회의 반응과 각국 정 부의 대응을 고려해 보아도 장기적으로 이익이 되기 때문이다. 따라서 대규모 자본 이 대규모의 토지수용을 해외에서 하려는 것은 자본의 논리를 볼 때 자연스러울 수 있다. 
그런데 문제는 다른 곳에서 발생한다. 어쩌면 언론들이 강조한 토지수탈은 복잡한 상황의 일부일 수 있다. 기업들에 대한 토지수탈의 논쟁이 진행되는 동안 세계식량 기구(FAO)가 중심이 되어 여기에 대한 좀 더 자세한 조사를 진행하였다. 그 결과 2009년 5월 25일 '토지수탈인가, 개발기회인가?(Land Grab or development opportunity?)'라는 보고서를 공식적으로 발행하였다.

이 보고서는 방대한 양의 인터뷰를 통해 정보를 정리했는데, 관가해서는 안되는 중요한 사실들이 드러나게 되었다. 요약하면 이렇다. ${ }^{16)}$

- 빈곤 국가들의 토지를 해외기업들이 빌리면서 기업 투자에 대한 책임, 사회기반 시설 개발, 고용 등에 대한 복잡한 점들이 평가되어야 함에도 해당 정부와 기업 들이 거래 과정에서 매우 간단하고 단순한 계약서를 만들어 처리하고 있었다.

- 기업들은 수입이 높고 시장에 접근이 쉬워 부가가치가 높은 토지를 원하게 된다, 문제는 그런 땅들의 경우 주민들이 점유하고는 있지만 정부에는 등록되어 있지 않은 토지들이 많다. 이로 인해 해외투자기업과 지역공동체는 심각한 분쟁을 만 들어 낼 수 있다.

- 토지 투자를 원하는 나라들의 다수가 지역 주민의 권리와 공동체의 이해, 생계 와 복지를 방어해낼 수 있는 법적인 혹은 제도적인 장치를 갖고 있지 않다.

- 따라서 수원국과 투자 기업 사이에 진행한 거래는 기업들이 수원국가 정부의 부 패에 기여하고 주민들을 배제하고 환경을 더욱 악화시키는 일에 기여할 소지가 있음을 동 보고서는 밝히고 있다.

결국 현재 대규모 기업들의 해외 식량투자는 환경과 빈곤을 개선하기보다 저해하 는 요소로 작용하고 있는 것이 현실이다.

16) 2000년 대 초반까지만 해도 소작 문제는 소규모 농가가 땅을 빌리는 형태를 취했지 만, 식량안보문제가 제기되자 소작은 빈곤 국가에 대해 대규모 자본이 해외 식량 투 자를 하기 위한 형태로 바뀌었다. 그 결과 식량 확보 보다 금융적 관심으로 개발에 대한 진지한 모색 보다 투기적인 성격으로 드러났다(FAO, 2009년). 


\section{2. 기후변화로 증가하는 환경난민}

\section{1) 기록1 - 기후변화가 원인인 수단 다르푸르(Darfur)의 참상}

1967년부터 1972년 동안 아프리카 사하라사막이 남쪽에 위치한 초원지대인 사헬지 역으로 $100 \mathrm{~km}$ 남진하면서 사헬 일대가 사막화된다. 원인은 인도양의 기후가 바뀐 것과 관련이 있다. 기후변화가 인도양의 기후를 바꾸면서 사헬 지역으로 가야 할 열 대몬순 패턴이 바뀌게 되었다. 이 사건은 인류가 역사를 기록한 수천 년 만에 처음 으로 발생이 사건이었다. 이로 인해 사하라사막 남쪽(Sub-Sahara) 사헬 지역에서 60 만 명이 굶어 죽었다. 국제사회는 기존의 사막(desert)이라는 개념과 다른 '사막화 (desertification)'라는 용어를 만들어내게 된다. 그 이후 1979년에 다시 한 번 사하 라사막이 남진하게 된다. 1979년부터 발생한 사막화는 이후 예상치 못한 극단적인 사건으로 나타났다. 국제사회에서 '대규모 폭력사태' 혹은 '인종청소'로 비난받는 수 단의 '다르푸르' 분쟁이 그것이다. 사막화는 1983년, 1984년에 수단 다르푸르에 대기 근을 발생시켜 10 만 명의 목숨을 앗아갔다. 수단은 매년 7월부터 9 월까지 우기(雨期) 인데, 1980 년대 이후 우기의 강우량은 그전과 비교해서 $40 \%$ 나 줄어들었다. (북(北)) 다르푸르에 있는 엘파셔 기상대 관측 자료)

그런데 정상적으로 비가 내리고 식량이 자급되던 과거에는 북쪽의 아랍 유목민들 이 다르푸르의 목초지에 자유롭게 들어와도 문제가 되지 않았다. 사막화, 가뭄이 오 래되자 다르푸르의 흑인 부족은 펜스를 치고 북쪽 유목민들의 진입을 막았다. 여기 서 다르푸르 분쟁의 싹이 자라나기 시작했다. 다르푸르의 인구는 20 세기 초에 100 만 명도 안 되었다. 그러나 분쟁이 발생한 2003년 당시에는 600 700만 명으로 추정될 정도로 인구가 늘었다. 다르푸르는 빈곤율은 최고 $61 \sim 72 \%$ 로 수단에서도 가장 가난 한 지역이다. 이곳에서 발생한 분쟁으로 22 만 명의 사람이 죽고 220 만 명의 난민이 발생했다. 가해자는 수단 정부군과 그 지원을 받는 아랍계 잔자위드(Janjaweed) 민 병대였고, 피해자는 다르푸르의 아프리카 흑인 토착민이었다. 결국 220 만 명의 토착 민들은 고향과 집을 등지고 $600 \mathrm{~km}$ 를 걸어 이웃 나라로 갔고, 이들은 지금도 비참한 난민생활을 하고 있다. ${ }^{17)}$

17) 처음 다르푸르 분쟁이 발생했을 때 수단에 있었던 인도주의 기구들은 기후변화와 사 
수단 다르푸르 분쟁은 기후변화와 사막화로 인한 물 부족, 생태 악화, 초지 소멸, 토지 퇴화에서 발생했다. 현재 다르푸르는 급속한 사막화로 인해 물 부족, 식량부족, 농·목축업의 낮은 생산성, 열악한 통치와 분쟁 해결 메커니즘의 붕괴, 생태와 경제 상황을 악화시키는 인구의 급증으로 극단적인 빈곤의 덫에 갇혀 있다.

정부와 잔자위드 민병대, 국민회복전선(NRF) 등 다르푸르 반군조직을 포함한 다르 푸르 평화협정 당사자들이 장기적인 평화유지의 열쇠로 강조한 것은 '빈곤문제 해결 을 위한 발전'이다. 저수시설, 수자원 시설 복구, 빗물을 모으는 간단한 방법의 대량 보급, 개량종 곡물 보급, 유목용 초지 확보, 조기가뭄 경보시스템 도입, 땔감과 식수 배급 등이 문제해결의 방책으로 제시되고 있다.

\section{2) 기록 2 - 가축을 잃은 몽골 유목민들}

2010년 몽골 자연환경 관광부 조사에 따르면 지난 100년간 지구 평균 기온이 $0.74^{\circ} \mathrm{C}$ 상승했지만, 몽골은 최근 60 년간 $2.1^{\circ} \mathrm{C}$ 상승했다고 한다. 그 결과 한반도의 7.4 배에 해당하는 국토의 $78 \%$ 에서 사막화가 진행되었고, 887 개의 강, 1,166 개의 호 수, 2,069 개의 샘과 연못이 사라졌다. 식물종의 4 분의 3 이 멸종하는 등 기후변화의 피해를 심각하게 입고 있다. ${ }^{18)}$

기후변화는 특히 유목을 생업으로 하는 몽골의 대다수 인구에 큰 피해를 주고 있 다. 2002 년 겨울 몽골을 덮친 영하 40 도가 넘는 한파로 인해 1,100 만여 마리의 가축 이 죽고, 이로 인해 12,000 여 가구가 삶의 터전을 잃는 결과를 가져왔다.

막화가 원인이라고 보지 않고 ‘집단살해’로 선언한다. 그러면서 미국과 유럽 등 국제 사회들이 적극 개입할 것을 요청한다. 이러한 개입 요구는 그 이후 정치적인 혹은 군 사적인 개입 논란으로 점화된다. 2007년 유엔은 다르푸르 분쟁의 원인을 기후변화와 사막화에 의한 생태계 악화로 보고 누가 다르푸르 분쟁의 주범인지를 제기하게 된다 (카너 폴리, 2010년, 266쪽).

18) 원래 몽골은 1990 년 초에는 사막이 전체 국토의 $46 \%$ 정도였다. 20 년 동안에 사막화 면적이 $78 \%$ 로 늘어나게 된다. 몽골의 사막화 확장으로 몽골은 한반도에 오는 황사와 미세먼지 발원지가 된다(Institute of Geoecology in Mongolia, 2014년). 
지난 2010년 2월부터 4월까지 석 달간 몽골에서 750 만 마리의 가축이 굶어 죽었 다. 2010년 2월부터 이상 기후로 인한 폭설이 계속되면서, 20 40센티미터의 눈이 몽골을 덮쳤다. 특히 눈보라를 포함해 영하 50 도의 극단적인 한파가 몰려와 가축들 이 풀을 찾지 못하고 굶어 죽었다. 이로 인해 몽골에는 9,000 가구, 4 만 3 천명의 환 경난민이 발생했다. ${ }^{19)}$

몽골 주민들은 많은 눈과 한파를 동반하면서 7년 혹은 8년마다 주기적으로 발생하 는 기상 악화를 '주드'(Dzud, 재앙)라고 부른다. '주드'가 발생해도 유목민들에게 조 금 힘들지만 그저 잘 넘기면 되는 자연현상 정도로 여겨져 왔다. 그런데 2002년 겨 울과 2010년 겨울에 발생한 주드는 과거와 전혀 달랐다. 몽골에서 발생한 혹독한 기 상악화는 지구 평균 기온 상승 $\left(0.74^{\circ} \mathrm{C}\right)$ 보다 3 배 $\left(2.1^{\circ} \mathrm{C}\right)$ 가 더 오른 기후변화가 주된 원인이다.

환경난민들은 더 이상 유목 생활을 할 수 없게 되어 결국 도시로 떠났다. 가축을 잃은 유목민들에게 당장의 생존이 급할 수밖에 없기 때문이다.

도시로 간 환경난민들에 대해 몽골 정부는 따로 거주할 곳을 마련해주지 못하고 있다. 그러다 보니 이들은 도시 주변에 불법 거주지를 형성해서 모여 산다. 불법 거 주이다 보니 수도나 전기의 혜택도 받지 못한다. 이들은 영하 40도까지 내려가는 추 운 겨울에 음식과 연료를 구하기 위해 쓰레기 더미를 뒤지며 살아간다.

몽골 수도 울란바타르시 송깅하이르 항구에는 다수의 환경난민들이 모여 살고 있다. 이제 여섯 살 정도의 어린이들이 움직이는 청소차에 올라가 위험하게 고철과 파지를 줍는다. 어른들은 작은 야산처럼 생긴 쓰레기장에서 고철과 비닐과 파지를 줍는다. 이 것이 환경난민들이 자신의 자존심을 지키는 거의 유일한 생존수단이다. 이런 사람들이 몽골의 수도 울란바타르시에만 30 만 명 이상 존재하는 것으로 추정되고 있다.

19) 몽골에서 가축이 죽고 환경 난민들이 발생해 유엔은 국제사회에 도움을 요청하지만 별로 반응이 없었다. 변방에 위치한 몽골이 겪은 이중적 피해라고도 할 수 있다 (Jaehoon, Lee Ph.D, 2012년). 


\section{3) 기록 3 - 세계 기후변화 두 번째 피해지역 미얀마}

2008년 5월 2일 새벽, 미얀마 남부 인도양 해변으로 밀려들어온 태풍 '나르기스' 로 인해 바닷물의 수위가 5 미터 이상 올라갔다. 지난 100 년간 미얀마에는 태풍이 오 지 않았다. 주로 인도양에서 발생한 태풍 사이클론은 이웃나라인 방글라데시로 갔다. 그러나 태국, 미얀마, 라오스, 인도네시아 일대에서 발생한 기후변화는 태풍의 진로 를 바꾸었다. 미얀마를 향해 태풍이 나아간 것이다. 이로 인해 인도양과 접한 에이어 워디 삼각주와 인근 섬에 살던 13 만 4 천명의 주민들이 사망했다. 인도 기상 당국이 보낸 나르기스의 위험성에 대해 4월 30일 전달을 받은 미얀마 기상청 툰루윈(Tun Lwin) 박사는 정부 당국에게 주민들을 긴급하게 대피시켜야 한다고 요청했지만 묵살 되었다. 희생자들의 다수는 힘이 없는 어린이들과 부녀자들 이었다. ${ }^{20)}$

즉각 언론을 통해 국제사회로 전해진 이 참상에 유엔과 각국 정부와 구호 단체, 기업과 시민들은 대규모의 구호물자와 지원비를 보냈다.

그렇지만 그 지원은 새로운 문제를 만들어 내었다. 긴급구호가 진행되었지만, 정말 필요한 것은 주민들이 빈곤으로부터 벗어나는 자립프로그램이었다.

그러나 문제가 발생한 당시에는 지구촌의 관심이 쏠리다가 언론이 관심을 갖지 않 게 되자 피해지역은 그대로 방치되었다. 또 다시 발생할 재해에 대한 아무런 대비책 이 없는 것이다.

2013년 3월 미얀마 남부 '나르기스' 피해지역을 방문한 기록은 다음과 같다. 나르 기스로 피해를 입은 지역에는 2008년 이후 태풍이 매년 발생하지만 태풍 대피소는 100 만 명이 사는 지역에 고작 두 개밖에 없었다. 피해지역을 재건하는데 10년 이상

20) 2013년 3월 툰루윈 박사를 인터뷰하면서 알게 된 것은 미얀마에는 나르기스와 같은 태풍도 문제가 되지만 더 큰 문제는 중부 미얀마의 건조화가 더 긴급하고 취약하다는 점을 강조했다. 이대로 가다가는 20년, 30년 뒤 미얀마는 미국의 텍사스와 같은 사막 화 지역으로 변화할 것이라고 경고했다. 과거에 비해 미얀마 중부지역의 강수량이 $10 \%$ 50\%로 줄어들면서 식량안보와 물문제가 새로운 도전으로 제기되고 있다고 한 다(오기출, 2013년). 
걸림에도 재건을 위한 국제 구호기구는 존재하지 않았다. 다만 유엔개발기구(UNDP) 미얀마 지부가 120 만 달러의 예산을 갖고 여성들에게 낮은 이자로 돈을 빌려주고 있 을 뿐이다. 나르기스 현장에는 당시 국제적인 지원을 받아 활동한 몇 개의 미얀마 국내 시민단체들만 쓸쓸히 남아 있었다.

툰루윈 박사에 따르면 기상이변에 해당하는 엘니노(El Nino)와 라니나(La Nina) 현상이 1980년대에는 5년 혹은 7년 주기로 발생했다. 그러나 최근에는 매년 혹은 2 년 주기로 발생한다고 한다. 아울러 미얀마 중부 건조지역 중 대한민국 면적에 달하 는 $87,000 \mathrm{~km}^{2}$ 가 건조화와 사막화로 피해를 입고 있다. 인구 1,500 만 명이 거주하고 있고, $2,500 \mathrm{~mm}$ 의 비가 내렸던 이 지역은 현재 극심한 건조화와 사막화로 $80 \%$ 이상 의 농촌 인구들이 빈곤선 이하로 근근이 생활하고 있다. ${ }^{21)}$

\section{4) 집으로 돌아갈 수 없는 환경난민들}

현재 유엔난민기구가 인정하는 '난민(難民)'이란 인종, 종교, 민족, 특정사회집단의 구성원 신분 또는 정치적인 의견을 이유로 박해받을 수 있는 사람들을 말한다. ${ }^{22) ~ ' ㅎ ㅘ ㄴ ~}$ 경난민'이란 환경 악화로 생활의 기반을 잃은 사람들이다. 그런데 환경난민은 인종, 종교, 민족, 정치적인 이유 등으로 박해받는 사람들이 아니라는 이유로 국제사회에서 난민으로 인정받지 못하고 있다. 이것이 환경난민의 문제를 악순환의 상황으로 몰아 가고 있다.

1980년대 이후 환경난민 문제가 본격적으로 드러난 지 30년이 지났다. 그런데도 환경난민이 국제사회에서 난민으로 공식화되지 않는 이유는 무엇일까? 무엇보다도 기후변화를 일으킨 선진국들이 환경난민을 공식적으로 인정할 경우 선진국으로 돌아 올 책임이 핵심으로 보인다. 문제는 환경난민들이 기후변화를 직접적으로 일으킨 책 임이 없다는 사실이다. 실제로 기후변화를 일으킨 선진국, 그리고 산업화된 국가들이 환경난민에 대한 책임이 있다.

21) Dr. Tun Lwin, 2003년.

22) 이는 한국 정부가 준용하는 난민 기준이기도 하다. 
전쟁난민들은 전쟁이 끝나면 집으로 돌아갈 수가 있다. 그렇지만 환경난민은 환경 의 악화로 삶의 기반을 잃어버렸기 때문에 돌아갈 집이 없다. 그들은 어디로 가야 하는가?

지금 전 세계적으로 이런 환경난민에 대한 정확한 집계가 되지 않고 있다. 다만 2011년 6월 ‘국내난민감시센터'와 ‘노르웨이 난민협의회’가 공동으로 발표한 보고서에 따르면 2010년 들어 4천 700만 명 이상 발생했다고 한다. 현재 기후변화로 인해 지구 촌의 28억 인구가 환경난민이 될 수 있는 위험지역에 거주하고 있다. 삶의 터전을 잃 어버리고 집으로 돌아가고 싶어도 되돌아갈 수 없는 사람들이 앞으로 늘어날 것이다.

그동안 인류 문명을 도약시킨 산업화, 대량 생산, 대량 소비가 이제는 거꾸로 인류 문명과 지구 생명의 붕괴를 촉진시키고 있다. 지구생명이 위기에 처하고, 환경난민이 빈곤의 덫에 갇힌 상태에서 나머지 인류는 살아남을 수 있을까? 여기에 대해 인류는 답을 해야 한다. 지구생명의 위기와 빈곤의 악순환 속에서 인류는 스스로를 구원할 수 없다. 기후변화의 시계를 멈추고 환경난민이 자립할 수 있도록 돕는 것, 단순하지 만 여기에 위기의 답이 있을 것이다.

\section{IV. 환경과 빈곤문제 대책을 찾아서}

\section{1. 국제적 가이드라인의 적용}

기후변화는 경작지와 방목지를 습격하여 토지퇴화 및 식량문제와 물 문제를 야기 한다. 그 결과 한편으로 저개발국에 대한 국제 자본의 토지 수탈 문제를 만들어 내 고, 다른 한편으로 단시간 내에 대규모 환경난민 발생과 극단적인 분쟁을 만들어 낸 다. 기후변화의 위험성은 기존의 빈곤 문제를 더욱 극단적이고 심각하게 악화시킨다. 문제는 그 해결이 단순하지 않다는 점이다. 그동안 기후변화에 대응해온 사례들을 보면 나무를 심거나 풀씨를 심어 생태복원을 하는 것에 한정된 경우가 많았다. ${ }^{23)}$ 푸

23) 한국국제협력단(KOICA)이 발간한 한국형 개발협력 모델(정우진, 2010년, 210쪽)을 보면 한국이 해외에 지원한 조림사업 중심의 활동들이 종합적 전략에 따라 사업이 선정되었다기보다 정치적 이해관계 속에서 홍보 효과를 위해 선정되어 단발적 사업 에 그쳤다는 평가가 있다. 
른아시아가 몽골에서 경험한 바를 정리하면 다음과 같다. 몽골 수도 울란바타르 $200 \mathrm{~km}$ 서쪽의 모래폭풍 발원지인 바양노르(Bayannuur) 지역에 2007년부터 나무를 심어 약 $120 \mathrm{ha}$ 의 땅에 숲을 만들었다. 당연히 주변 경관이 좋아지고 생태가 복원되 었다. 2013년부터 숲이 조성된 곳으로 바양노르 지역의 부자들과 권력을 가진 사람 들이 이사를 오고 집을 짓기 시작했다. 그리고 이들은 숲과 생태가 복원된 조림지 안에서 집을 짓기 위해 푸른아시아가 요청한 토지사용기간 연장을 거부했다. 만일, 이 조림지를 통해 협동조합을 구성하고 활동하는 지역 주민들이 나서지 않았다면 생 태가 복원된 아름다운 숲은 부자들과 권력을 가진 사람들의 정원으로 바뀌었을 것이 다. 그리고 그 근처에 살아가는 빈곤한 주민들이 이 조림지에 대한 공동 소유의지가 없었다면 이들은 다시 변방으로 쫓겨났을 것이다.

제I장

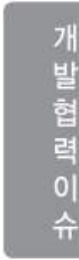

제II장

제피장

제IV장

기후변화에 대한 대책은 나무 심고 풀씨 심는 단순한 행동으로 해결되지 않는다는 에피소드이다. 기후변화와 사막화 그리고 환경문제는 현지에 살아가는 주민들의 빈 곤문제와는 동전의 양면이다. 현지 주민들의 역량개발을 통한 빈곤문제 해결과 결합 하지 않으면 기후변화에 대한 성과를 만들어 낼 수 없다.

이러한 다소 복잡한 환경과 빈곤의 문제를 해결하기 위해 유엔과 유엔식량기구 등 은 오랜 기간의 경험과 정보, 성공과 실패 사례, 지식을 통합해서 국제적 가이드라인 을 만들어 왔다.

이 국제적 가이드라인은 가장 선진적인 지식과 경험을 정리한 결과이기 때문에 기 획과 실행, 성과에 대한 평가를 하는 데 중요한 기준이 될 수 있다. 이것을 지키는 것은 시행착오를 줄이기 위한 길이기도 하다.

\section{1) 유엔사막화방지협약(UNCCD) 가이드라인}

1994년 기후변화와 토지퇴화, 건조화로 피해를 입은 지구촌의 사막화를 방지하기 위해 만들어진 유엔사막화방지협약은 현재 194개국이 참여하고 있다. 특히 2007년 9 월 스페인 마드리드에서 열린 제8회 당사국 총회에서 향후 10 년 동안의 사막화방지 협약 이행을 강화하기 위한 ' 10 개년 전략계획과 프레임워크'를 만장일치로 채택했다. 
- 의무: 사막화방지협약 의무로 빈곤퇴치전략과 사막화방지를 연계(UNCCD 협약 4조, 6조)

- 마드리드 ' 10 개년 전략계획과 프레임워크' 4 대 전략적 목표

(1) 피해를 입고 있는 사람들의 생활조건 향상

(2) 피해를 입고 있는 지역의 생태계 조건 향상

(3) 사막화방지협약의 효과적 이행을 통해 지구적 혜택 발전24)

(4) 국내행위자와 국제행위자 사이에 효과적인 동반자적 관계 구축, 사막화방지 협약의 이행을 지원할 수 있는 자원 동원

\section{2) 유엔식량농업기구(FAO)의 권고}

앞서 살펴보았듯이 $\mathrm{FAO}$ 는 환경개발국제연구소(IIED), 국제농업개발기금(IFAD)과 공동 으로 2009년 5월 25일, 자국의 식량안보(Food Security)에 불안을 안고 있는 식량수입국 들의 해외 농지 취득 움직임에 대해 ‘토지수탈인가? 개발기회인가?'라는 보고서를 내었 다. 여기서 토지수탈의 오명에 노출된 투자 자본과 수혜국가(Recipient governments), 이에 대응해야 할 시민사회조직과 국제기구들을 위한 가이드라인을 권고했다. 그 중에 투 자 자본과 시민사회조직에 대한 권고사항을 중심으로 소개하고자 한다. ${ }^{25)}$

- 투자 자본(투자국 포함)에 대한 권고

(1) 대규모 농업프로젝트를 관리할 역량 평가: 투자 자본은 농업개발보다 금융 적 거래의 경향이 있음. 이것이 토지수탈로 이어질 수 있음. 이를 반전시킬 관리역량이 필요함.

(2) 투자 자본의 이미지와 명성을 고려: 부패정권과 인권 탄압 정권과 거래하고 지지하는 것으로 보일 수 있음. 취약한 식량안보에 노출된 나라들이 토지수

24) 지구적 혜택의 의미는 세계 3대 환경협약이 상호 기여를 한다는 것이다. 즉 3대 환경 협약 중 하나인 유엔사막화방지협약의 실천을 통해 유엔기후변화협약의 기후변화 대 응, 생물다양성협약의 생물다양성에 기여한다는 것이다.

25) 국제기구들을 위한 가이드라인의 경우 중요한 데 국제기구들이 영향력을 발휘해서 투 자 자본, 수혜 국가, 지역주민, 시민사회조직에 대한 조정자 역할을 해야 한다는 것이 요체이다. 특히 국제기구들은 지역주민들이 전통적으로 점유하는 토지들에 대해 주민 집단 등록을 하도록 권고하는 방안이 중요하다. 
탈로 인식한다는 점을 고려한 책임 있는 행위가 필요함.

(3) 지역공동체를 고려하지 않는 장기적인 임대(50년, 99년)는 지속가능성을 방 해함.

(4) 지역공동체에 대한 세심한 평가, 장기적으로 지역공동체의 이익을 실현해야 함.

(5) 지역공동체의 참여라는 명확한 원칙을 지켜야 함.

- 농촌 빈민을 지원하는 조직들을 위한 권고

(1) 토지 거래의 투명성을 증진하는 정책제안

(2) 토지 투자 절차의 각 단계마다 투자 자본이 지켜야 할 약속 이행을 요구

(3) 토지 투자로 영향을 받는 사람들에 대한 합법적인 지원: 정부, 투자자본, 공동체의 파트너십 구축, 합법적인 컨설팅, 주민들에 대한 협상 기술 훈련, 공적 소송 등 지원

(4) 지역공동체 토지에 대한 주민 집단 등록 지원: 아프리카 등에서 얻은 교훈 은 주민 집단 등록이 강력한 힘을 발휘하고 주민의 토지권리를 방어했다는 점에서 권고함.

\section{2. 사례: 지속가능한 토지경영(Sustainable Land Management, SLM) 모델}

기후변화와 환경난민이 발생하는 빈곤현장에서 국제적 가이드라인을 준수하면서 활동을 한 사례를 소개하면 아래와 같다.

2014년 10월 유엔사막화방지협약(UNCCD)은 뉴스레터(UNCCD News Issue 6.3) 를 통해 기후변화 사막화 방지, 그리고 빈곤 저감을 통해 지속가능한 토지경영의 성 공모델을 소개한다.

'심각한 혹한으로 그가 키우던 가축들이 모두 죽자 그는 모든 재산을 잃게 된다. 전 재산을 잃은 몽골 유목민 치벨 불간 키시크(Tseebel Bulgan Khisig)는 생활비를 벌기 위해 그의 고향 마을, 기후변화로 이미 사막화된 바양노르(Bayannuur)를 떠났 다. 그 후 그는 수도 울란바타르에 가서 건설노동자가 되었다. 울란바타르에서도 생 활이 너무 힘들어 4 년이 지나 고향에 돌아 왔다. 고향에 와서 그의 앞에 펼쳐진 광 
경을 보고 눈을 의심했다. "황폐했던 제 고향은 완전히 바뀌어 있었습니다. 바뀐 땅 에는 나무와 초지들로 가득했고, 더 이상 사막화된 땅이 아니었습니다. 저는 이 모든 것이 푸른아시아(Green Asia Network)의 성과였음을 알게 되었습니다."

그는 푸른아시아가 어떻게 이 모든 것을 해냈는지 배우고 싶었다. 그래서 그 이후 푸른아시아와 함께 하게 되었고, 그곳에서 농·임업 기술을 배울 수 있게 되었다(유엔 사막화방지협약(UNCCD) 뉴스레터, 2014, 14쪽).

2014년 6월 17일, 유엔사막화방지협약(UNCCD)은 미국 워싱턴에 소재한 세계은행 본부에서 각 나라가 추천한 76 개의 사막화방지 모델 중 유엔사막화방지협약 '생명의 토지상(Land for Life)' 최우수상을 발표했다. 생명의 토지상은 환경노벨상으로 불리 는 상으로 유엔이 지속가능한 토지경영(SLM)의 성공모델을 발굴, 사막화로 피해를 입고 있는 110 개 나라 21 억 명에게 적극 권고하기 위해 2011년 제정되었다.

2014년 생명의 토지상 최우수상으로 푸른아시아가 2000년 이후 몽골에서 15년 간 진행해온 주민참여, 주민자립형 모델을 선정했다.

기후변화와 사막화는 인류가 유사 이래 처음으로 겪는 사건이다. 따라서 기후변화 에 대응해온 선행 사례가 없다는 점에서 2014년 유엔이 선정한 푸른아시아 모델을 자세히 소개해보자. 앞의 국제적 가이드라인이 어떻게 적용되어 있는지 살펴볼 수 있다. ${ }^{26)}$

\section{1) 사막화 방지 지속가능한 지역개발모델 만들어}

한국에 본부가 있는 푸른아시아는 지난 2000년부터 한국과 몽골의 다양한 파트너 들이 협력해서 현재까지 몽골의 6개 사막화, 환경난민 발생지역에서 $450 \mathrm{ha}$, 450,000 그루의 나무를 심고 생태복원을 했다. 푸른아시아는 몽골과 한국에서 그 동 안 25,000 명에 달하는 자원봉사자들을 조직하고, 매년 150 가구에 달하는 환경난민들 의 자립 역량을 개발하고 있다. 사막화되어 완전히 황폐화된 토지의 초지 생산량은

26) 유엔사막화방지협약, 2014년, http://newbox.unccd.int. 
0 인데 토양 복원을 통해 1 ha에 3.2 톤의 초지를 생산했다. 기후변화대응을 위한 사막 화 방지 및 지속가능한 토지경영 모델을 개발, 주민참여를 통한 지역개발이 생태복 원의 근본 처방임을 실제 사례로 보여주었다. 이는 환경 문제뿐만 아니라 환경 파괴 지역 주민들의 역량강화를 기반으로 한 기후변화 적응사업으로 주민참여와 주민자립 을 목표로 삼고 있는 통합적인 접근 방식이다.

\section{2) 환경난민들이 생태복원에 참여, 지역사회 발전으로}

푸른아시아는 최근 지구촌에서 논의하고 있는 지속가능발전(SDGs)의 요체인 환경, 사회, 경제 세 분야에 초점을 맞춰 10년 전부터 지속가능한 생태복원을 추구해 왔다. 토지와 산림의 복원사업을 통해서 사막화로 피해를 입은 지역사회가 경제적으로 다 시 일어설 수 있는 기회를 제공하고 주민 스스로 추진할 수 있도록 돕는 모델이다. 주로 환경난민으로 구성된 주민들은 푸른아시아 프로그램에 참여해 숲 조성을 통한 생태복원 프로젝트와 농·임업에 필요한 지식과 기술들을 익힌다. 푸른아시아 활동가 들은 주민들과 1 년 단위로 생활을 함께 한다. 이 현장 활동가들로부터 주민들은 생계 유지와 지역사회를 발전시킬 기술과 경험을 습득하게 된다.

\section{<그림 1> 푸른아시아 지속가능개발 모델}

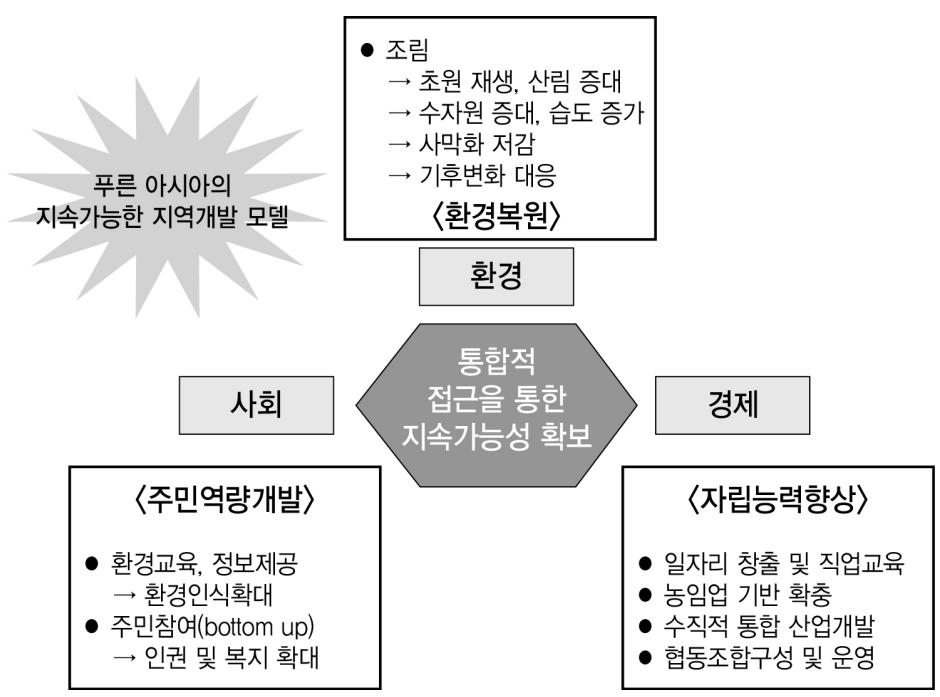


푸른아시아는 현장 활동이 어려운 겨울에 집중적으로 주민교육 및 주민조직 사업 을 진행한다. 이때는 주민들이 가져야할 비전과 활동, 추진 프로젝트 등에 대해 보다 정교한 인식을 갖게 해 프로젝트 참여의 동기부여를 높인다. 또 이들이 환경문제에 보다 적극적인 사고를 할 수 있게 토론과 역할 교육 등을 진행한다. 물론 추가적으 로 녹지 계획, 농업, 온실 운영 및 경영과 같은 전문적인 과정도 교육한다.

\section{<그림 2> 주민교육}

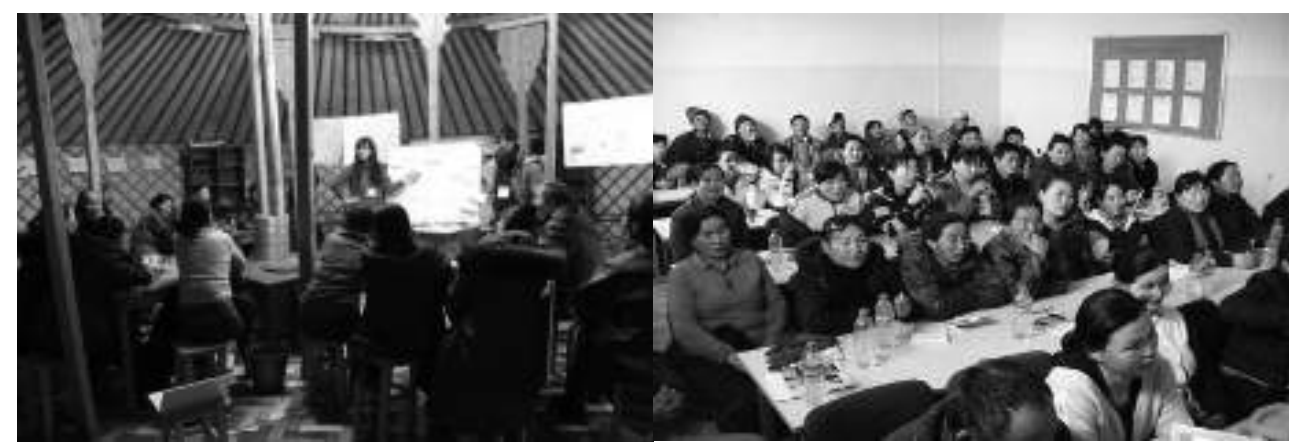

교육과정을 이수한 주민들은 주민들 스스로가 토론하여 지역의 환경과 특성에 맞 는 지속가능한 토지경영(SLM)의 기조를 정하고 역할분담을 맡는다. 과거 유실수 단 지로 유명했으나 최근 급격히 사막화된 바양노르 지역의 경우 사라져가는 수자원(호 수) 복원, 친환경 에너지(태양광 발전)를 통한 숲의 복원, 유실수 재배, 양묘, 영농 등을 집중적으로 추진하고 있다.

각 지역사회에서 수익을 창출하기 위해 주민들은 유실수 재배와 비닐하우스 영농 에 직접 관리인으로 참여한다. 이를 통해 얻게 되는 수익은 주민공제회가 관리하는 공동기금으로 적립하고 있다. 
3) 모래먼지폭풍의 발생빈도 감소

<그림 3> 황사 발생 빈도 및 이동 경로

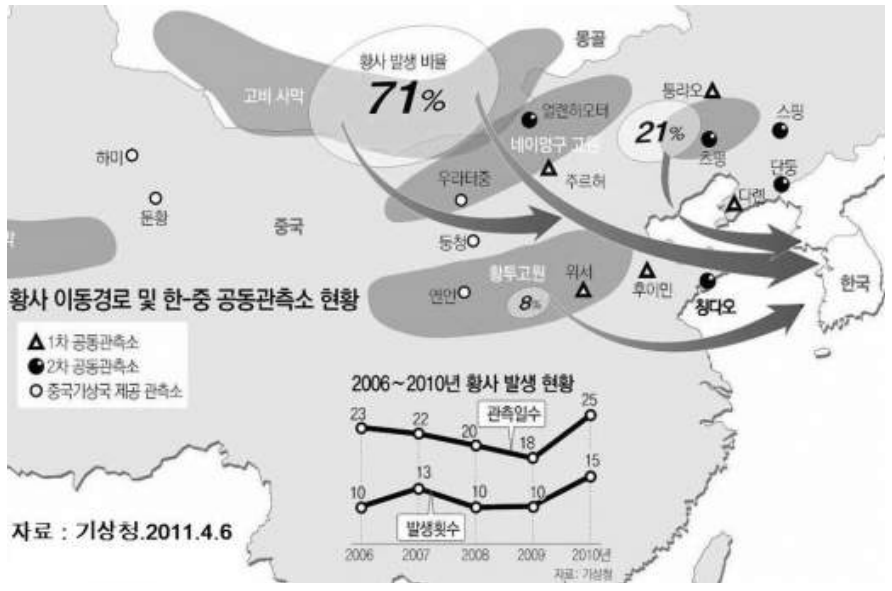

〈표 3〉 몽골의 황사 빈도 및 모래 먼지 폭풍 발생일

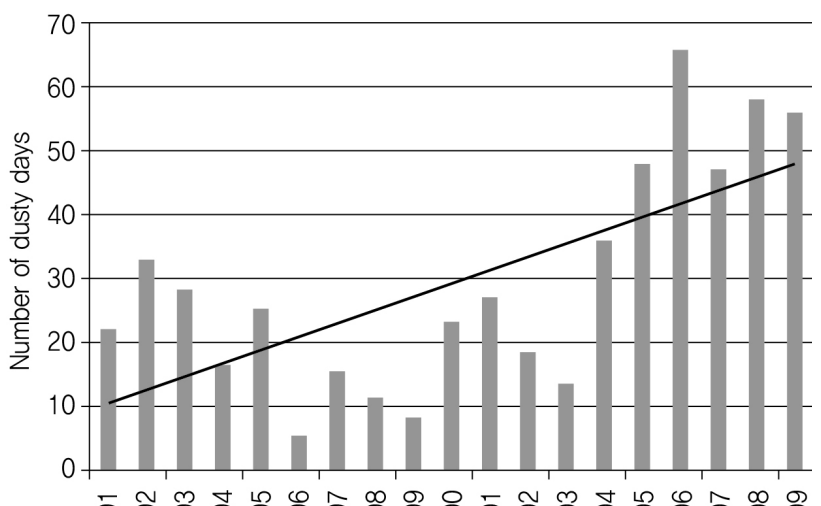

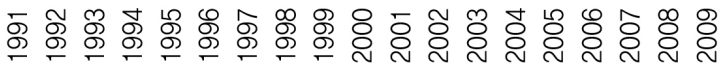

자료: Zhamsueva et al. 2011

몽골에서 초지가 사라지면서 1991년 2009년 20년 간 모래 먼지 폭풍의 발생 빈도 는 연 20 일에서 60 일로 3 배 가까이 늘었다. ${ }^{27)}$

27) 중국은 정부 차원의 대대적인 사막화 방지 사업으로 현재 모래 먼지 발생 일수는 감 소했다. 1년 2회-5회 정도로 줄었지만 몽골의 모래 먼지 폭풍의 발생 빈도가 늘어남 으로써 한국에 오는 황사 발생의 $53 \%$ 에서 $71 \%$ 가 몽골에서 온다고 한다(푸른아시아, 한국 기상청 자료 2011년 인용, 2014년, 3쪽). 
솦 조성 이후 주민들을 대상으로 설문조사를 실시했을 때 마을 주변의 모래먼지가 체감할 정도로 감소했다는 반응을 얻을 수 있었다. 2007년부터 7년간 바양노르 지역 $120 \mathrm{ha}$ 의 사막화지역에 숲을 조성했다. 2007년 당시 바양노르는 마을이 $1,200 \mathrm{ha}$ 정 도의 크기이고 모래 폭풍의 발원지였다. 사막화방지 솦을 조성한 결과 솦 규모의 10 배가 되는 바양노르 마을에서 모래 폭풍이 발생하지 않고 있다. 이는 생태복원 프로 그램의 영향을 보여주는 부분이다. 또한, 이러한 모습은 몽골의 6 개 지역에서 모두 일관되게 나타나고 있다.

\section{4) 주민들에게 양묘사업, 농작물재배 기회 제공}

기후변화 사막화지역에서 토지 복구를 위해 솦을 만드는 조림 프로젝트는 약 5년 의 시간을 필요로 한다. 이 과정에서 주민들은 양묘사업을 통해 수익을 얻는다. 성장 한 묘목은 3 달러에 팔리게 된다. 예를 들면, 바양노르와 에르덴 지역에서는 매년 약 2 만 3만 그루의 유실수 묘목이 팔려나가는데, 이는 35 명의 현지 참가 주민들이 연 6 만 9만 달러의 수익을 창출할 수 있는 규모이다. 또한, 현지인들은 과일 재배 및 농작물 재배와 같은 농업에도 종사하는데, 대표적인 유실수인 차차르간(비타민나무) 과 우흐린누드(블랙커런트) 열매는 각각 $\mathrm{kg}$ 당 3 달러와 5 달러에 팔린다. 이 결과 이 미 심어진 과실수(차차르간: 27,000 그루, 우흐린누드: 10,000 그루)에서 생산되는 열매를 주민들이 직접 판매를 하고 창출된 이익은 주민회의를 통해 어떻게 쓰일 것 인지 결정된다.

\section{<그림 4> 주민들이 수확한 차차르간과 우흐린누드 열매}
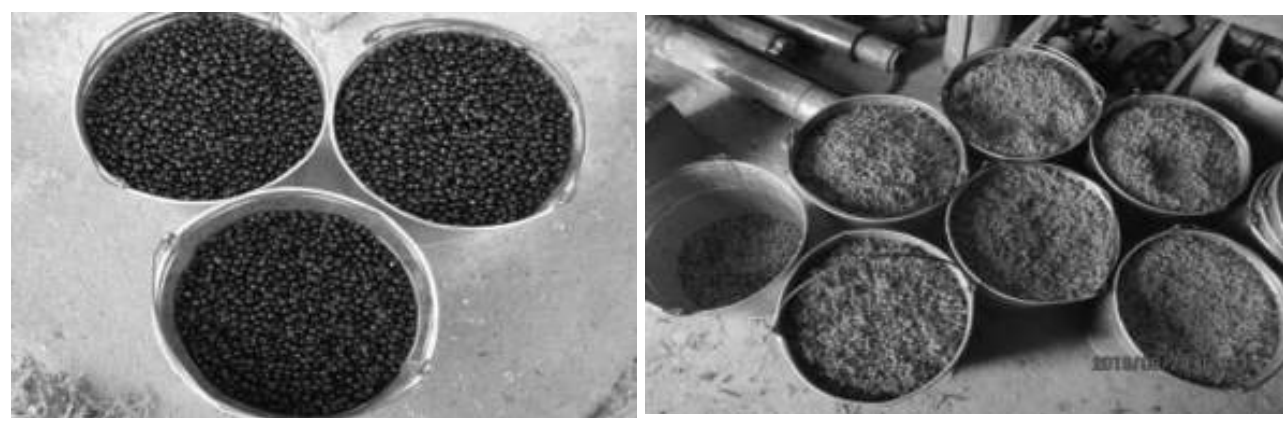
5) 지속가능 생태모델 아시아로 전파

지속적인 노력과 실험 끝에 푸른아시아의 '지속가능한 생태모델'은 몽골 여러 지역 에 전파했고, 이 사업의 지속가능성을 증명해냈다. 프로젝트에 이용되는 나무는 평균 생존율이 $80 \%$ 정도이다. 2013년부터 미얀마에도 지부를 설립하면서 이 성공모델을 전파하고 지속가능한 토지경영 모델로써 아시아 여러 나라로 확대하고 있다.

\section{<그림 5> 생태복원을 하고 있는 주민들}
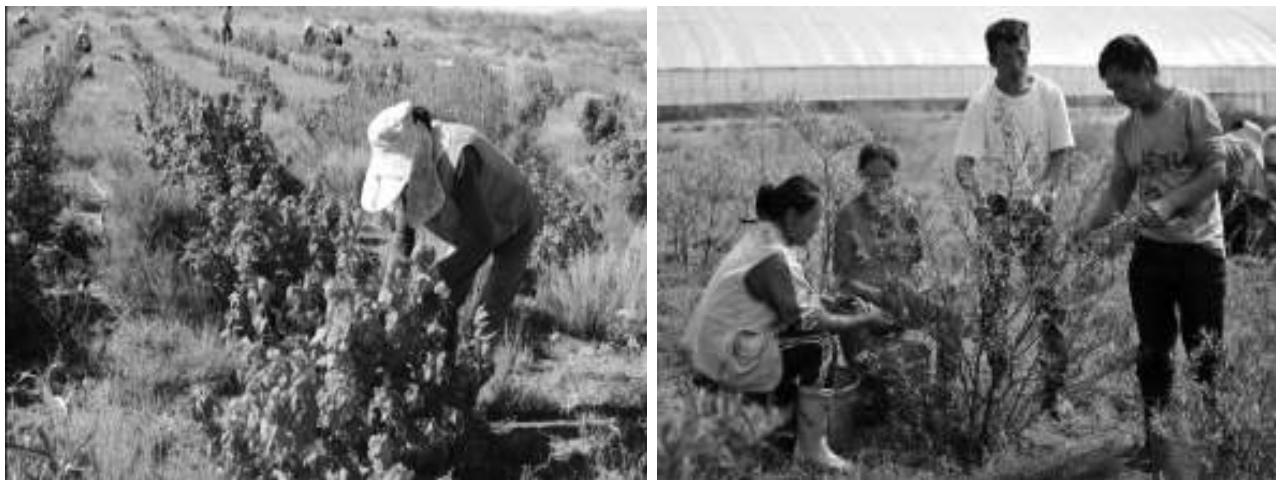

제 I장

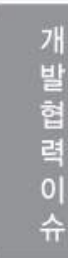

제II장

제III장

제IV장

6) 에드보커시(정보공유와 교육프로그램 진행)

2014년, 푸른아시아의 사막화 방지 전략을 상세하게 기술한 전략리포트를 영어판 으로 발행하여 500 여 국제 민간단체들과 유엔기구들에게 보급하고 있다. ${ }^{28)}$ 이는 다 른 파트너와 국제단체들에게도 전달되어, 같은 목적으로 토지 황폐화 방지에 기여할 수 있게 하고 있다. 또한, 한국과 몽골에서 교육 프로그램도 추진 중인데, 이는 주로 대학이나 고등학교에서 결성된 환경단체나 자원봉사단체의 형태로 진행된다. 학생 자원봉사자들은 환경에 대한 지식을 습득하며 사막화 피해 지역에 직접 참여하여 활 동하는 기회를 제공받는다. 학생들은 교실내의 수업뿐만 아니라 직접 몸으로 경험하 는 활동을 통해 토지 황폐화의 심각성과 영향에 대한 깊은 이해를 가지게 된다.

28) Cultivating a Common future, 2014년. 
이 활동 중 가장 혁신적인 프로그램은 '에코투어’라고 할 수 있는데, 이는 참가자 들이 직접 기후변화 지역을 체험함으로써 환경의 변화와 영향에 대한 인식을 효과적 으로 증진시키는 방법으로 평가받고 있다. '에코투어'는 기후변화 및 사막화 교육과 병행되며, 숲 조성 프로젝트에 참여할 수 있는 기회를 제공하기도 한다. 참가자들은 매년 600 여명의 한국인과 3,000 명 이상의 몽골인으로 다양하게 이루어져 높은 참여 율을 기록하고 있다.

\section{<그림 6> 몽골 학생들과 한국 학생들이 에코투어 과정에서 협력하는 모습}

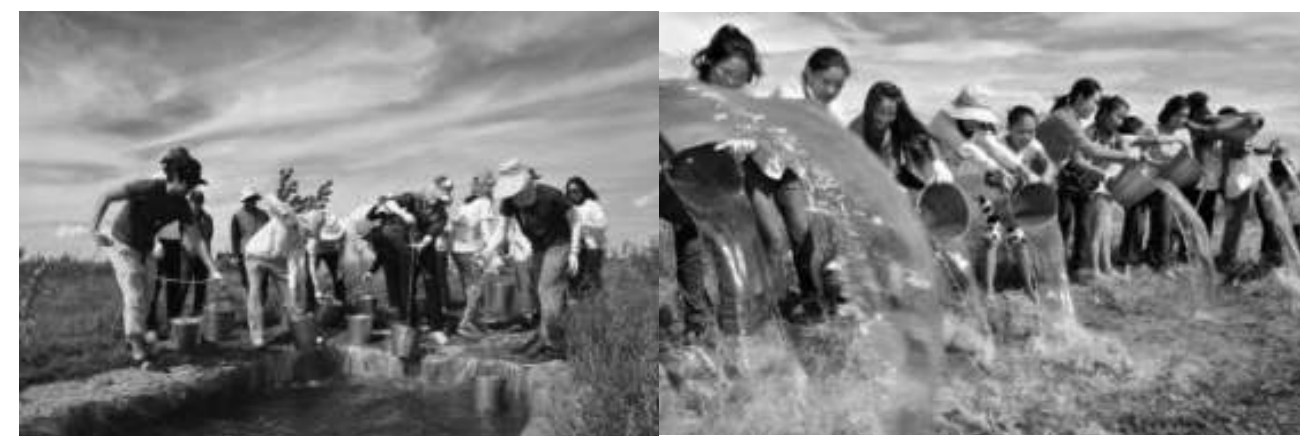

\section{3. 정보와 아이디어, 지식공유 플랫폼 제안: 테라시아(TerrAsia)를 만들어야}

인류가 처음으로 겪고 있는 기후변화와 빈곤 문제를 공동으로 해결하기 위해서는 우선 기후변화와 빈곤 현장에 적용 가능한 주민참여 풀뿌리 모델이 필요하다. 아울 러 이를 폭넓게 실현하기 위해서는 기후변화 피해 국가와 기후변화에 책임이 있는 국가가 공동으로 협력하는 것이 성공의 열쇠다. 그래서 성공모델을 공유하면서 확산 할 수 있는 국제적인 플랫폼이 구성되어야 효과적이다. 이러한 노력은 대규모 투자 자본이 국제적인 가이드라인을 지킬 수 있도록 안내함으로써 토지 수탈이라는 오명 에서 벗어나 문제를 함께 해결하는 파트너의 역할을 하게할 수 있을 것이다.

2005년 10월 유럽과 아프리카가 공동으로 기후변화·사막화 등으로 피해를 입고 있 는 아프리카 지역과 주민들을 위한 사건을 만들었다. 그것은 테라프리카(TerrAfrica) 의 결성이다. 
테라프리카는 땅을 의미하는 테라(Terra)와 아프리카(Africa)를 결합한 것으로 기 후변화의 피해를 입고 있는 아프리카에서 유럽이 공동으로 지속가능한 토지경영을 하자는 것이다. 아프리카 땅을 살리자는 국제적인 플랫폼이다. 여기에 23 개 아프리 카 사하라 남쪽(Sub-Sahara) 국가들과 유럽 연합, 유엔, 유엔 관련 국제기구들, 세 계은행, 민간단체(NGO), 기업들이 대거 참여를 했다. 목표는 향후 12 년 간 아프리카 의 땅을 회복하기 위한 최선의 정보, 아이디어, 지식을 공유하자는 데 있다고 밝혔 다. 이를 위해 세계은행이 우선 40 억 달러를 제공했다.

이 목표에 따라 테라프리카는 스스로의 임무를 다음과 같은 세 가지 영역으로 정 리를 한다.

\section{제I장}

- 연합체 건설(Coalition Building)

- 지식 경영(Knowledge and management)

- 지역, 정부, 정부간, 국제적인 규모로 장기간 지속가능한 토지와 수자원개발에 투자

현재 테라프리카는 아프리카와 유럽이 공동으로 지속가능한 토지 경영을 하는 중 요한 플랫폼이 되고 있다.

현재 기후변화의 10 개 재난 지역 중 7 곳이 아시아에 있고 가장 많은 환경 난민들 이 발생하는 지역이 아시아이다.

그런 점에서 아프리카와 유럽에 이어 아시아의 환경과 빈곤을 해결할 수 있는 협 력 플랫폼인 테라시아(TerrAsia)를 만들 필요가 있다. 테라프리카와 같이 피해지역을 지원할 정부와 피해지역의 정부가 협력하면서, 유엔, 유엔 기구들, 지역개발은행 $(\mathrm{ADB})$, 기업, 민간단체(NGO)들이 참여할 수 있을 것이다. 테라시아를 통해 최선의 정보, 아이디어, 지식을 공유하면서 성공모델을 현장에 적용할 수 있고, ${ }^{29)}$ 아울러 한

29) 2010년부터 활동을 해온 영국 기후개발지식네트워크(CDKN)의 사례를 벤치마킹해서 적용할 수 있다.

$\mathrm{CDKN}$ 은 3개 대륙(아시아, 아프리카, 남미) 내 개도국을 지원하기 위하여 기후 과학 자, 리서치 전문가, 경제학자, 컨설턴트, 프로젝트 매니저, 지식공유 전문가로 구성된 
국, 중국, 몽골, 일본이 공동으로 처한 미세먼지 문제를 해결하는 협력체를 구성할 수 있다.

\section{〈그림7> 테라시아 프로젝트}

\section{중앙아시아(사막화)}

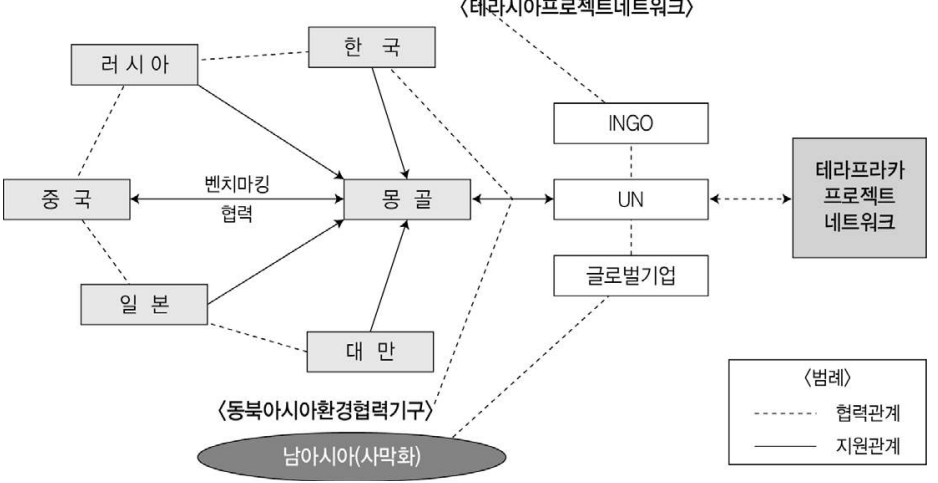

다행히 아시아 25 개 나라의 기후변화와 환경관련 단체들이 2015 년 4 월 서울에서 '기 후변화 대응을 위한 아시아시민사회콘퍼런스'를 개최한다. 여기서 회의만 하는 것이 아 니라, 기후변화 대응을 위한 지속적인 플랫폼을 만들기 위한 결정을 한다고 한다.

우선 시민사회에 속한 25 개 나라의 민간단체들이 테라시아를 만드는 촉매의 역할 을 할 수 있을 것으로 보인다. 기후변화와 환경위기, 빈곤의 위기에 놓인 현재 할 수 있는 일이라면 무엇이든지 시도해 보아야한다. 그렇지 않으면 아무 것도 변화하지 않기 때문이다. 결국 아시아에서 환경과 빈곤문제를 해결하는 답은 테라시아를 만들 어 가이드라인과 성공사례, 정보와 최선의 아이디어, 자원을 공유하고 협력하는 것이 아닐까 한다. 결국 테라프리카에서 시작한 흐름이 아시아에서는 테라시아를 만들고 라틴아메리카에서는 테라틴아메리카를 만들어 협력하는 것이 지구촌을 생명으로 연 결하는 새로운 길이 아닐까 한다. 조심스럽지만 대책의 결론으로 제안하고 싶다.

팀원을 국제적 컨설팅 회사 및 대륙별 $\mathrm{NGO}$ 로 구성된 조직과 연대해서 서비스를 제 공하고 있다. 1) 기후 개발 전략 및 계획 수립 2) 개도국의 녹색 금융 접근성 향상 3) 기후 관련 재난 위험 관리를 통한 기후 적응 향상 4) 최빈국 및 도서국에 대한 국 제적 기후 협상 지원을 주요과제로 현재까지 100 여개의 성과를 $\mathrm{CDKN}$ 의 자금으로 지원을 했다(삼일회계법인, 2012년, 168쪽). 


\section{참고문헌}

\section{- 국내문헌}

김민주, 2014, “곡물가 폭등, 재앙은 시작됐다”, 서울, 한국경제메거진 오기출, 2013, “기후변화 위기와 새로운 도전", 서울, 푸른아시아 오기출, 2013, “미얀마 기후변화 현황 1차 조사", 서울, 푸른아시아 이성훈, 2014, “Post-2015 개발의제와 시민사회”, 『2014 한국의 개발협력』, 서울, 한국수출입은행

정우진, 2010, 『한국형 개발협력 모델』, 경기도 성남, 한국국제협력단 카너 폴리, 2010, 『왜 인도주의는 전쟁으로 치닫는가?』, 서울, 마티 푸른아시아, 2014, "기후변화 대응 및 사막화, 황사 방지를 위한 몽골 서울의 숲 조성사업”, 서울, 푸른아시아

한석호, 2012 , “국제 곡물가격 급등과 애그플레이션”, 서울, 경향신문

\section{- 국외문헌}

The Economist, 2012, “Market strategy/Global Window”, London, the Economist

Green Asia Network, 2014, "Cultivating a Common Future: 5 Year Strategy Report of Green Asia Network”, Seoul, Green Asia Network

IIED, FAO, JLIFAD, 2009, “Land Grab or development opportunity?", London/Rome, Russel Press

Institute of Geoecology in Mongolia, 2014, "Desertification Atlas of Mongolia』, Ulanbaatar, Ministry of Environment and Green Development

Jaehoon, Lee Ph.D, 2012, “Combating Desertification with the Sustainable Regional Development Model: The Case of Green Asia in Mongolia”, Seoul, World Bank Institute

Dr. Tun Lwin, 2013, "Is Our Environment Secured? Climate Perspective in Myanmar", London, British Council 
UNCCD, 2014, "Land for Life Winner 1: Green Asia Network(GAN)", http://newbox.unccd.int

United Nations, 2014, "Climate Change Summit Not about Talk, but Action”, New York, UN

Vivienne Walt, 2008, “The Breadbasket of South Korea: Madagascar”, U.S, Time

World Bank, 2014, “Climate Change Overview”, Washington, D.C, World Bank

World Bank, 2014, "Ending poverty might become impossible because of climate change”, Washington, D.C, The Carbon Brief

World Bank, 2014, “Speech by World Bank Group President Jim Yong Kim: Tackling the Most Difficult Problems: Infrastructure. Ebola and Climate Change", Washington, D.C, World Bank 